$\begin{array}{ccc}\text { Tersedia online di: http://ejournal-balitbang.kkp.go.id/index.php/jppi } & \text { JURNAL } \\ \text { e-mail:jppi.puslitbangkan@ gmail.com } & \text { PENELITIAN } \\ \text { PERIKANAN } & \text { IDDONESIA } \\ \text { JURNALPENELITIANPERIKANANINDONESIA } & \text { Volume 23 Nomor 4 Desember 2017 } \\ \text { e-ISSN: 2502-6542 } & \\ \text { Nomor Akreditasi: 653/AU3/P2MI-LIPI/07/2015 }\end{array}$

\title{
TIPE PERIKANAN DAN STATUS SUMBERDAYA IKAN TERUBUK (Tenualosa macrura, Bleeker 1852), DI PERAIRAN ESTUARIN BENGKALIS DAN SELAT PANJANG
}

\section{FISHERIES TYPE AND STATUS OF TERUBUK (Tenualosa macrura, Bleeker 1852) RESOURCES IN THE ESTUARINE OF BENGKALIS AND SELAT PANJANG}

\author{
Suwarso ${ }^{\star 1}$, Muh. Taufik ${ }^{1}$ dan Akhmad Zamroni ${ }^{1}$ \\ ${ }^{1}$ Peneliti pada Balai Riset Perikanan Laut, Jakarta \\ ${ }^{1}$ Komplek Raiser Ikan Hias Cibinong. JI. Raya Bogor KM. 47 Nanggewer Mekar, Cibinong, Bogor 16912 \\ Teregistrasi I tanggal: 03 Mei 2017; Diterima setelah perbaikan tanggal: 27 Desember 2017; \\ Disetujui terbit tanggal: 03 Januari 2018
}

\begin{abstract}
ABSTRAK
Ikan terubuk (Tenualosa spp.) adalah ikan estuarin bersifat 'protandrous hermaphrodite' dan endemik di estuarin sekitar Bengkalis. Jenis Tenualosa macrura ditemukan di sekitar Bengkalis (Riau), jenis T. ilisha di sekitar Labuhan Batu dan Labuhan Bilik (Sumatra Utara), sedangkan T. toli ditemukan di perairan pantai barat Pemangkat (Kalbar). Sumber daya terubuk di sekitar Bengkalis saat ini sangat menurun akibat eksploitasi dan recruitment overfishing meskipun pembatasan penangkapan telah diterapkan. Tulisan ini membahas status sumber daya ikan terubuk di sekitar Bengkalis dan Selat Panjang berdasarkan data monitoring hasil tangkapan periode 2014-2016 dan observasi lapangan selama 2015-2016. Ikan terubuk merupakan ikan dominan dari enam jenis hasil tangkapan pada gill net, jumlahnya sekitar $15 \%$ dari total hasil tangkapan, upaya penangkapan tergolong intensif sehingga penurunan upaya yang dilakukan ternyata kurang signifikan, bahkan pada saat close season dan close area (September sampai November) upaya penangkapan cenderung tinggi. Kondisi ini tentu tidak sesuai dengan tujuan perlindungan terbatas dan konservasi jenis yang diterapkan. Penurunan populasi terubuk tampak nyata dalam bentuk hasil tangkapan (CPUE), sex ratio maupun produksi pendaratan. Ikan kategori "Pias" (ikan jantan) tetap dominan dan semakin banyak, sebaliknya kategori "Terubuk" (ikan betina matang gonad) semakin sedikit, artinya ukuran rata-rata ikan juga semakin kecil. Keberadaan populasi ikan terubuk di sekitar P. Tiga (Kab. Kepulauan Meranti) dengan kondisi matang gonad dan secara genetik memiliki pola DNA yang sama dengan yang berada di Bengkalis. Perluasan daerah konservasi dan perlindungan terbatas terhadap stok-stok tersebut disarankan.
\end{abstract}

Kata Kunci: Ikan terubuk; estuarine; hasil tangkapan; sex ratio; Bengkalis; Selat Panjang

\begin{abstract}
The terubuk (Tenualosa spp) or shads, is a estuarine and endemic 'protandrous hermaphrodite' fish species. Species Tenualosa macrura is found in estuarine waters around Bengkalis (Riau Province), T. ilisha around Labuhan Batu and Labuhan Bilik (North Sumatera Province) while T. toli in west coast of Pemangkat (West Kalimantan Province). The terubuk reosurce in Bengkalis water is heavily degraded due to high exploitation and recruitment overfishing eventhough fishing limitation is applied. This paper is discussing the status of terubuk/longtail shad (Tenualosa macrura) resources in Bengkalis estuarine and Selat Panjang waters (Kabupaten Kepulauan Meranti) base on data of 2014-2016 catch monitoring data and field observation during 2015-2016. Terubuk is one of 6 dominant catches from gillnet, contributing about $15 \%$ of all catch. The fishing effort was so intensive even though management measure is applied to reduce its exploitation. During the close season when fishing on terubuk is banned (in September to November) as well as the ban in close area, the fishing effort has been still high. This condition is not in line with the objective of protecting
\end{abstract}


the terubuk resources. Therefore, this condition must be changed and returned to objective of "limited protection" and "species conservation" by adopting a more strict rule on limiting fishing effort on terubuk through an evaluation. The decreasing of terubuk population can be seen from CPUE, sex ratio and also in landing, short time (2012 - 2016) and long time (18 years). In overall, the "Pias" (adult male) individuals remainned dominant and wereeven getting more in number, while the "Terubuk" (adult female) on the contrary, which means that the average size of actual fish cought was getting smaller. The existence of terubuk population around Pulau Tiga (Kabupaten Kepulauan Meranti) with mature gonad would share the same genetic pattern with population from Bengkalis. This explaines the connectivity between two stocks, at least there might be another spawning stock other than Bengkalis's. The expand of the conservation area and limited protection on those stocks is highly recommended.

\section{Keywords: Terubuk; Estuarine; Catch; Sex ratio PENDAHULUAN}

Ikan terubuk (Tenualosa spp.; Alosinae, Fam. Clupeidae) merupakan komoditas perikanan yang penting, bersifat strategis dan memiliki nilai ekonomi. Ikan ini hidup di habitat pantai dan estuarin, umumnya bersifat 'protandrous hermaphodite' dimana setiap individu ikan akan mengalami perubahan seksualitas dari jantan menjadi betina pada ukuran/umur tertentu. Dari lima spesies terubuk yang dikenal di Asia, tiga spesies diantaranya ditemukan di Indonesia yaitu $T$. macrura diketahui hanya tersebar di perairan estuari sekitar Bengkalis, T. ilisha di Labuhan Batu dan Labuhan Bilik (Sumatera Utara) serta Serawak (Brewer \& Blaber, 1997), dan T. toli ditemukan di Serawak juga di perairan pantai Kalimantan Barat (Suwarso, 2014). Dua spesies lainnya adalah $T$. reevsii dan $T$. thibaudeaui; masing-masing tersebar di Vietnam dan China.

Di daerah Bengkalis terubuk ( $T$. macrura) sejak lama menjadi primadona sehingga terus menerus dieksplotasi, selain harga 'telur'nya cukup mahal mencapai kurang-lebih Rp. 12 juta/kg, dagingnya juga dikonsumsi. "Telur" yang diambil sebenarnya adalah gonad ikan betina dalam kondisi matang (mature). Pengambilan ikan terubuk yang sedang bertelur secara terus menerus telah berdampak negatif terhadap populasi ikan terubuk. Penurunan populasi terus berlangsung sejak tahun 60an (Ahmad et al., 1995), disamping disebabkan oleh recruitment overfishing (effort), diperkirakan juga adanya tekanan lingkungan (penyempitan habitat) akibat degradasi lingkungan Sungai Siak oleh polusi serbuk kayu (Brewer \& Blaber, 1997), limbah rumah tangga serta transportasi. Hingga tahun 50 an terubuk dapat dijumpai dalam jumlah melimpah dengan hasil tangkapan 2.000-3.000 ekor per kapal ukuran <5 GT, tahun 80an hasil tangkapan jumlahnya terbatas hanya beberapa kilogram. Suwarso \& Merta (1997) melaporkan produksi ikan terubuk di Bengkalis pada 1997 berkisar antara 0,5-10 ton/bulan atau sekitar 437 ribu ekor/bulan dengan nilai 3,6-175 juta rupiah. Hasil monitoring saat itu menunjukkan hasil tangkapan
(CPUE) sangat rendah berkisar antara 3-95 ekor/trip atau 0,5-11 kg/trip (Merta et al., 1999). Meskipun saat ini tidak lagi menjadi target penangkapan, namun ikan terubuk masih tertangkap (alat tangkap gill net terubuk), terutama pada bulan-bulan diluar close season-close areas (daerah sekitar muara Sei Pakning pada periode bulan gelap antara September sampai November).

Tulisan ini membahas status dan kondisi sumberdaya ikan terubuk di perairan estuari Bengkalis berdasarkan data monitoring hasil tangkapan ikan terubuk pada perikanan gill net di tiga kecamatan di Kabupaten Bengkalis pada periode 2014-2016. Selain sebagai pembaharuan data kelimpahan terubuk juga digunakan untuk menilai status populasi setelah peraturan tentang close season dan close areas ditetapkan (Keputusan Menteri Kelautan dan Perikanan RI No. Kep. 59/Men/2011 tentang Penetapan Status Perlindungan Terbatas Jenis Ikan Terubuk, Tenualosa macrura; Peraturan Menteri Kelautan dan Perikanan RI No. Per. 03/Men/2010 tentang Tata Cara Penetapan Status Perlindungan Jenis Ikan; dan Peraturan Pemerintah RI No. 60 Tahun 2007 tentang Konservasi Sumberdaya Ikan). Kajian status sumberdaya terubuk di Selat Panjang ditekankan pada aspek biologi terkait kematangan seksual ikan dan studi komparasi genetik serta kondisi populasi berdasarkan hasil observasi.

\section{BAHAN DAN METODE}

Contoh ikan terubuk diperoleh dari hasil tangkapan jaring terubuk (gill net) yang melakukan penangkapan di perairan estuarin sekitar Bengkalis selama Januari 2014 sampai Mei 2016. Kapal penangkap yang digunakan berukuran kurang dari 5 GT. Selama periode survei dilakukan pencacahan hasil tangkapan serta observasi lapangan untuk mendapatkan informasi tentang operasional perikanan. Pencacahan hasil tangkapan dilakukan di tiga kecamatan pada 2014, yaitu Bengkalis (2 desa), Bukit Batu (8 desa) dan Siak Kecil (1 desa); sedangkan pada 2015-2016 hanya di Kecamatan Bukit Batu karena dianggap 
dapat mewakili seluruh populasi. Secara keseluruhan pencacahan dilakukan pada delapan kelompok nelayan dengan 89 orang nelayan jaring gill net. Kondisi perikanan terubuk di Selat Panjang diperoleh melalui observasi lapangan pada Juni dan September terhadap beberapa kelompok nelayan di desa Kepau Baru (Kecamatan Tebing Tinggi Timur), Kota Selat Panjang dan Tanjung Samak.

Indek kelimpahan ikan (Catch per unit of effort/ CPUE) diperoleh berdasarkan data hasil tangkapan alat gill net yang mendarat selama Januari 2014 sampai Mei 2016 dengan analisis deskriptif dan statistik secara grafis yang dilaksanakan untuk mengetahui kecenderungan yang terjadi pada pola fluktuasi CPUE, upaya penangkapan dan sex ratio. Identifikasi spesies mengacu Munroe \& Wongratana (1999) dan Gloerfelt \& Kailola (1980).

\section{HASIL DAN BAHASAN \\ Hasil}

\section{Keragaan Perikanan Gill net}

Menurut Dinas Kelautan dan Perikanan Kabupaten Bengkalis pada 2014 tercatat sekitar 1.545 unit alat tangkap gill net yang aktif di wilayah Kabupaten Bengkalis (model EL2); alat tangkap lain berupa trammel net (586 unit), gombang (155 unit), rawai dasar tetap (228 unit), pengerih (407 unit) dan togok (33 unit). Dari jumlah tersebut sekitar $64 \%$ kapal gill net menggunakan kapal motor ukuran <5 GT, 26\% menggunakan kapal motor 5-10 GT, sisanya menggunakan perahu motor tempel. Estimasi produksi perikanan laut di seluruh Kabupaten Bengkalis diperkirakan 2.295 ton dan alat tangkap gill net memberi kontribusi paling besar (72\%), sisanya berasal dari trammel net (11\%), rawai dasar $(8 \%)$, gombang $(3 \%)$ dan pengerih $(6 \%)$. Produksi alat gill net sebagian besar (67\%) berasal dari armada ukuran $<5$ GT, 5\% berasal dari armada 5-10 GT.

\section{Komposisi Jenis Ikan yang Tertangkap Gill Net}

Tercatat sekitar 20 spesies ikan yang tertangkap dengan jaring gill net di perairan estuarin Bengkalis. Pada saat ini, secara umum ikan terubuk sebenarnya tidak lagi menjadi target penangkapan terutama di Bengkalis, walaupun dari hasil monitoring selama periode 2014 sampai Mei 2016 ikan terubuk masih tetap tercatat dalam hasil tangkapan.

Dari hasil monitoring pada 2014-2015, hasil tangkapan gill net dominan adalah ikan lomek (Harpodon nehereus) sebanyak 48\% atau $17.567 \mathrm{~kg}$; selain itu, tercatat lima jenis ikan dominan lain seperti ikan terubuk ( T. macrura) 15\% (5.596 kg), ikan biang (Septipina) 12\% (4.599 kg), tengiri 7\% (2.563 kg), debuk 4\% (1.440 kg), serta jenis lainnya kurang dari $3 \%$ (pari, hiu, malong, senangin, parang-parang, puput, kelampai, kakap putih dan lainnya) (Gambar 1). Ikan lomek, terubuk, biang dan tengiri merupakan empat jenis utama yang sering tertangkap jaring. Diantara delapan jenis alat tangkap yang dimonitor, alat tangkap gill net paling umum dipakai serta memberi kontribusi produksi paling besar (74\%), sisanya (26\%) berasal dari jaring apollo, pancing rawai, jaring kurau dan beberapa alat lainnya.
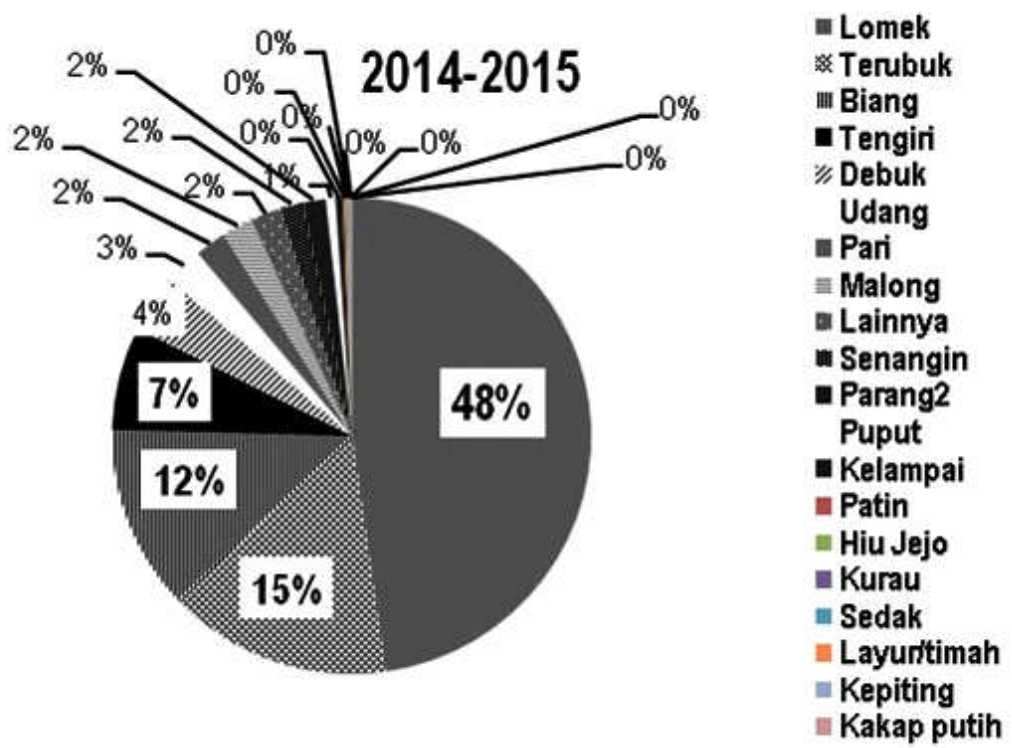

Gambar 1. Sebanyak 20 jenis ikan yang tertangkap gill net di perairan estuarin sekitar Bengkalis, 2014-2015. Figure 1. A number of 20 fish species caught by the gill nets around the estuarine of Bengkalis, 2014-2015. 
Komposisi jenis ikan yang tertangkap gill net bervariasi menurut lokasi (kecamatan) dan waktu (tahunan, musiman). Di Kecamatan Bengkalis ikan tengiri, parang-parang, biang dan puput paling dominan tertangkap, masing-masing $44 \%, 10 \%, 12 \%$ dan $7 \%$, sedangkan hasil tangkapan ikan terubuk hanya $2 \%$; di Kecamatan Bukit Batu jenis ikan lomek dan biang dominan, masing-masing 58\% dan 14\%, tangkapan ikan terubuk tercatat lebih banyak (sekitar 22\%); sedangkan di Kecamatan Siak Kecil tiga jenis dominan adalah biang, lomek dan terubuk, masingmasing sekitar 37\%, 35\% dan 18\% (Gambar 2). Perbedaan prosentase jumlah ikan terubuk yang didaratkan di Bengkalis dan Bukit Batu diperkirakan terkait dengan makin sedikitnya populasi terubuk di daerah penangkapan nelayan Bengkalis serta pergeseran target ke arah jenis-jenis ikan pelagis yang relatif besar.

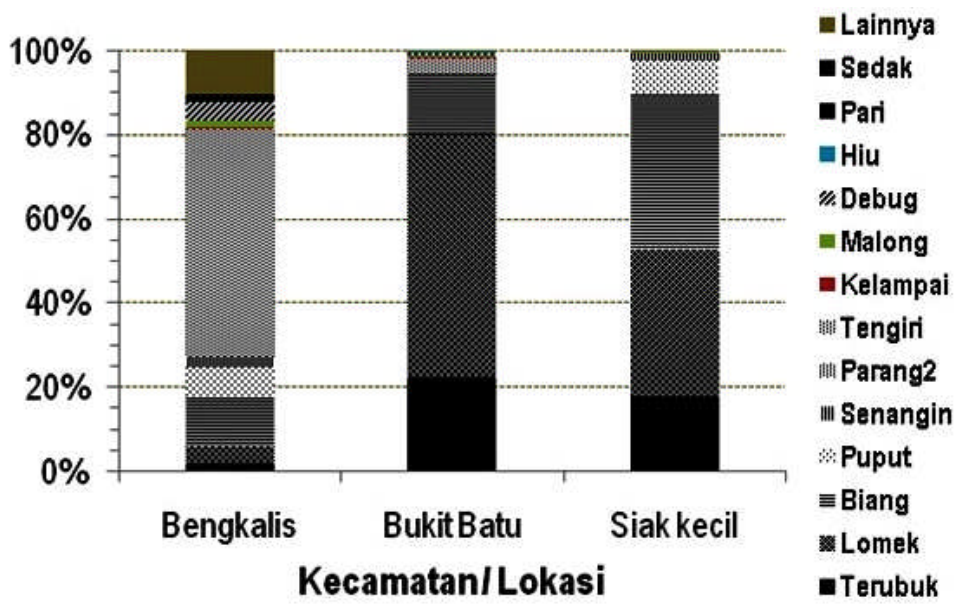

Gambar 2. Variasi komposisi hasil tangkapan gill net yang didaratkan di Kecamatan Bengkalis, Bukit Batu dan Siak Kecil, 2014.

Figure 2. Variation of the catch composition of gill nets landed in the district of Bengkalis, Bukit Batu and Siak Kecil, 2014.

Ikan lomek merupakan jenis paling dominan di Bukit Batu kira-kira $50 \%$ dari total hasil tangkapan; jumlah ini bertambah pada 2015 menjadi sekitar $65 \%$. Peningkatan prosentase ikan lomek diduga berhubungan dengan perubahan komunitas yang terjadi dalam habitat estuarin, menurunnya populasi satu jenis ikan menyebabkan meningkatnya jenis yang lain seperti lomek. Tiga jenis dominan lainnya adalah ikan terubuk (20\% pada 2014$)$, biang $(15 \%)$ dan tengiri (9\%). Pada 2015 prosentase ketiga jenis tersebut makin sedikit masing-masing terubuk (15\%), biang (11\%) dan tengiri (1\%). Fluktuasi bulanan dari komposisi jenis hasil tangkapan gill net yang didaratkan di Bukit Batu diperlihatkan pada Gambar 3. Prosentase lebih tinggi dari hasil tangkapan terubuk pada 2014 terlihat antara Januari sampai Juni (musim barat dan musim timur), pada September-Oktober (musim tangkapan terubuk) lebih sedikit. Hal ini menandakan pada saat musim tangkapan (juga merupakan 'musim pemijahan' ikan terubuk) aktivitas penangkapan diduga menurun sesuai upaya konservasi yang diterapkan (hasil kerjasama penelitian Balai Penelitian Perikanan Laut dengan Dinas Kelautan dan Perikanan Kab. Bengkalis tahun 2014).

\section{Bukit Batu}

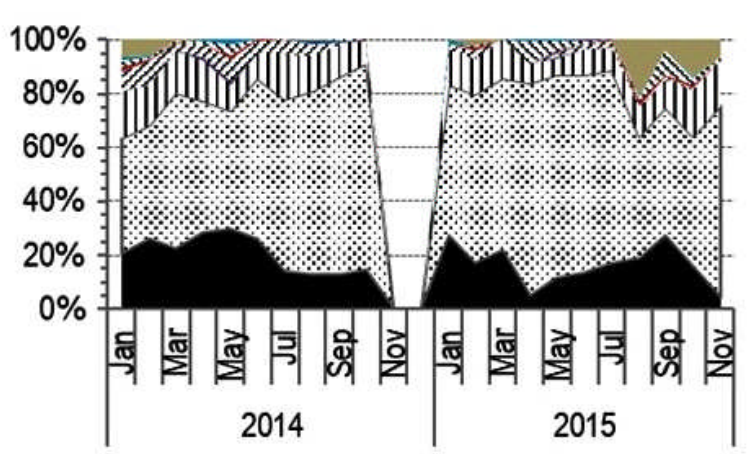

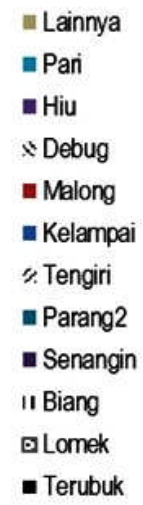

Gambar 3. Fluktuasi komposisi jenis hasil tangkapan gill net yang didaratkan di Kecamatan Bukit Batu, 2014-2015.

Figure 3. Fluctuation of catch composition of gill nets landed in the district of Bukit Batu, 2014-2015. 


\section{Aktivitas Penangkapan}

Dari hasil monitoring selama tahun $2014 \mathrm{di}$ Kecamatan Bengkalis (2 desa), Bukit Batu (8 desa) dan Siak Kecil (1 desa) terhadap total 8 kelompok nelayan dan 89 orang nelayan gill net, tercatat tiga zona penangkapan utama dari alat tangkap gill net, yaitu (a) Selat Padang, (b) Selat Bengkalis, (c) Selat Lalang, serta (c) Selat Malaka (utara pulau Bengkalis). Sebagian besar aktivitas nelayan gill net (83\%) tercatat sebanyak 780 trip penangkapan di Bukit Batu selama Januari-Oktober, di Bengkalis (Januari-Mei) sebanyak 75 trip (8\%) dan Siak Kecil 87 trip (9\%). Selain itu, teridentifikasi sembilan lokasi penangkapan dari alat tangkap gill net seperti terlihat pada Gambar 4. Lokasi penangkapan tersebar di Selat Bengkalis, Selat Padang dan Selat Lalang; hanya sekitar 16\% aktivitas berada di sekitar S. Pakning.
Hasil monitoring terhadap aktivitas penangkapan nelayan Bukit Batu selama 2014-2015 menunjukkan adanya penurunan jumlah trip rata-rata secara signifikan dari 78 trip/bulan pada 2014 (42 nelayan contoh) menjadi 45 trip/bulan pada 2015 (28 nelayan), tetapi sedikit penurunan jumlah trip per nelayan gill net dari 19 trip/nelayan pada 2014 menjadi 18 trip/ nelayan, atau penurunan jumlah trip hanya sekitar $5 \%$. Indikasi kesadaran nelayan tentang makin sedikitnya ikan terubuk dan konservasi sumberdaya diperkirakan melatar belakangi hal tersebut sehingga upaya penangkapan secara keseluruhan menurun. Fluktuasi aktivitas penangkapan nelayan gill net (jumlah trip) terlihat pada Gambar 5. Secara umum selama penelitian di lapangan tidak terlihat penurunan yang signifikan pada saat periode close season dan close area pada Oktober-November.

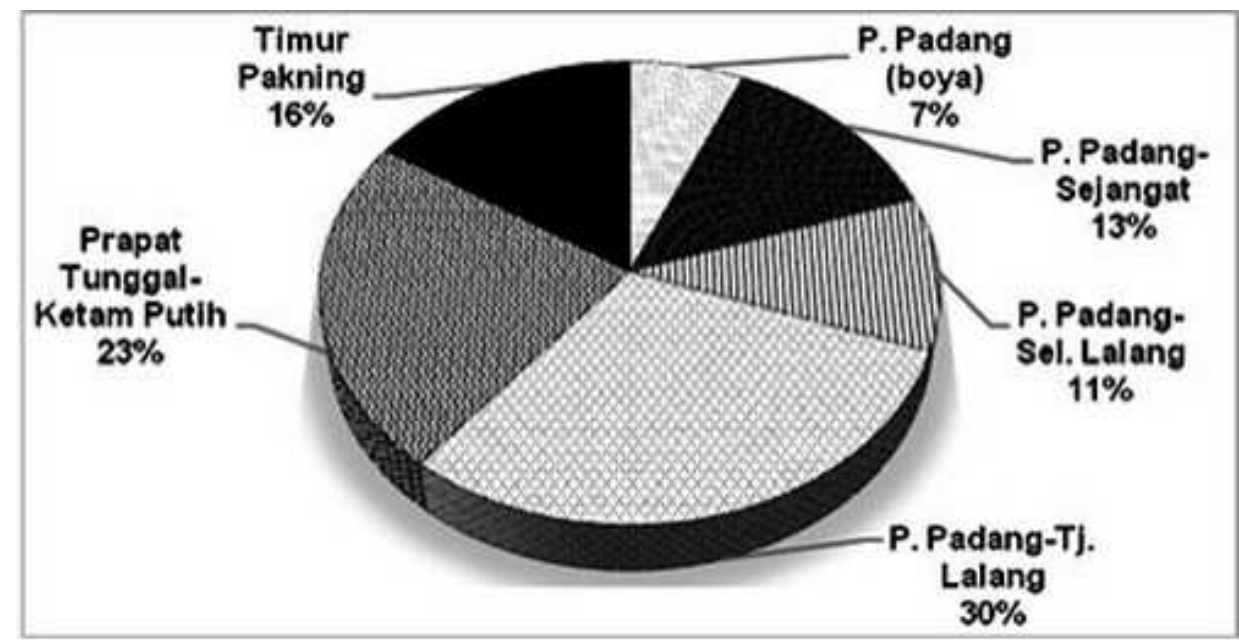

Gambar 4. Frekuensi aktivitas penangkapan (jumlah trip) nelayan gill net menurut lokasi penangkapan, 2014. Figure 4. Fishing activity frequency (numbers of trips) of gill nets according to the fishing grounds, 2014.

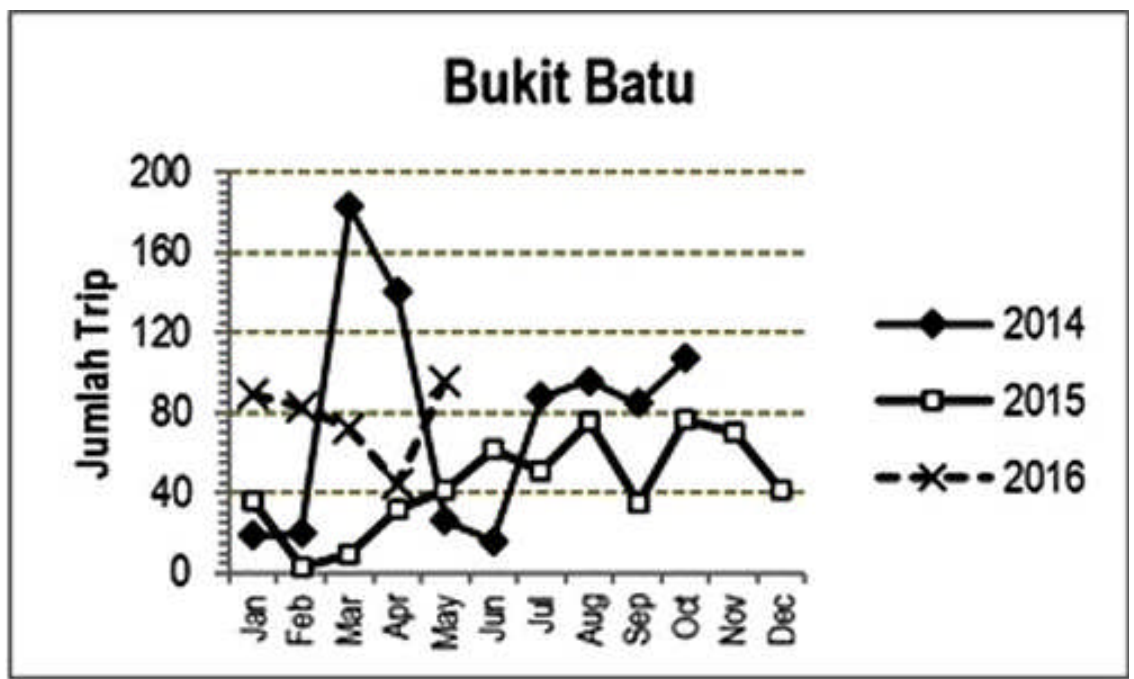

Gambar 5. Fluktuasi jumlah trips nelayan gill net Bukit Batu di perairan estuarin sekitar Bengkalis pada 20142015.

Figure 5. Fluctuation of trip numbers of gill nets in Bukit Batu estuarine in 2014-2015. 


\section{Hasil Tangkapan Gill net}

Dari total upaya sebanyak 2.135 trip penangkapan dalam periode 2014-2015 tampak hasil tangkapan gill net bervariasi menurut lokasi dan waktu. Rata-rata hasil tangkapan sekitar 19,0 kg, hasil tangkapan maksimum dapat mencapai $217 \mathrm{~kg}$; namun tercatat 'trip gagal' (hasil dibawah $5 \mathrm{~kg}$ ) sebanyak 317 trips (15\%). Hasil tangkapan per unit upaya (CPUE) alat jaring dari nelayan Bengkalis menunjukkan lebih tinggi (sekitar 39 kg/trip; pada Januari-Mei 2014) dibandingkan nelayan Siak Kecil (6,2 kg/trip; pada Juli-September) dan nelayan Bukit Batu kira-kira (18,8 kg/trip; pada 2014-2015) (Gambar 6).

Berdasarkan hasil tangkapan nelayan Bukit Batu dan 'CPUE'sebagai 'indeks kelimpahan' ikan dapat diduga kelimpahan ikan lebih banyak terjadi antara Maret-Mei, sedang pada bulan lainnya lebih sedikit. Sementara berdasarkan alat tangkap, hasil tangkapan per unit upaya (CPUE) alat gill net sekitar 23,3 kg/ trip pada 2014, turun menjadi $10,8 \mathrm{~kg} /$ trip pada 2015 ; jaring apollo kira-kira 5,2 kg/trip (2014-2015), jaring kurau dapat mencapai 58 kg/trip. Gambar 7 menunjukkan fluktuasi hasil tangkapan per unit upaya (CPUE) alat gill netdi sekitar Bengkalis. Peningkatan hasil tangkapan mulai terlihat pada Februari, puncak penangkapan antara Maret-April (CPUE sekitar 35-36 kg/trip), pada Mei menurun (CPUE = $25 \mathrm{~kg} /$ trip); sedangkan antara Juni November CPUE relatif tetap antara 9-14 kg/trip.

\section{Hasil Tangkapan Terubuk (kategori "Terubuk" dan “Pias")}

"Terubuk" adalah kategori ikan betina, ukuran di atas $21 \mathrm{~cm}$ panjang standard (standard-length, SL) dan umumnya matang telur; sedangkan "pias" adalah ikan-ikan jantan dewasa, ukuran di bawah $21 \mathrm{~cm} \mathrm{SL}$. Hasil tangkapan ikan terubuk dari keseluruhan trip penangkapan gill net tercatat sekitar $17 \%$ (4.906 kg) dari total tangkapan jaring $(23.859 \mathrm{~kg})$. Hasil tangkapan per unit upaya (CPUE) dapat digunakan sebagai indek kelimpahan ikan. Data monitoring selama 2014-2016 menunjukkan nilai CPUE ikan terubuk berpola sama dengan yang ditunjukkan oleh total hasil tangkapan alat jaring (Gambar 7). CPUE alat jaring sekitar 23,3 kg/trip, sedang CPUE ikan terubuk sekitar 4,5 kg/trip. Puncak kelimpahan terjadi antara Maret sampai Mei (2014). Untuk ikan terubuk sendiri (gabungan antara kategori 'terubuk' dan 'pias') puncak CPUE (dalam kg/trip) terjadi pada Maret-April (8-10 kg/trip), sedangkan dalam unit ekor/trip puncak lebih tinggi terjadi sekitar September (8 ekor/trip); pada Maret-April CPUE sekitar 4 ekor/trip (Gambar 7). Rincian CPUE ikan terubuk berdasarkan kategori ukuran ('terubuk' dan 'pias') dijelaskan pada Gambar 8. Penurunan CPUE ikan terubuk pada Juli sampai Oktober menjelaskan penurunan upaya penangkapan (jumlah trip) pada waktu-waktu tersebut terkait regulasi 'close season' (September sampai November).

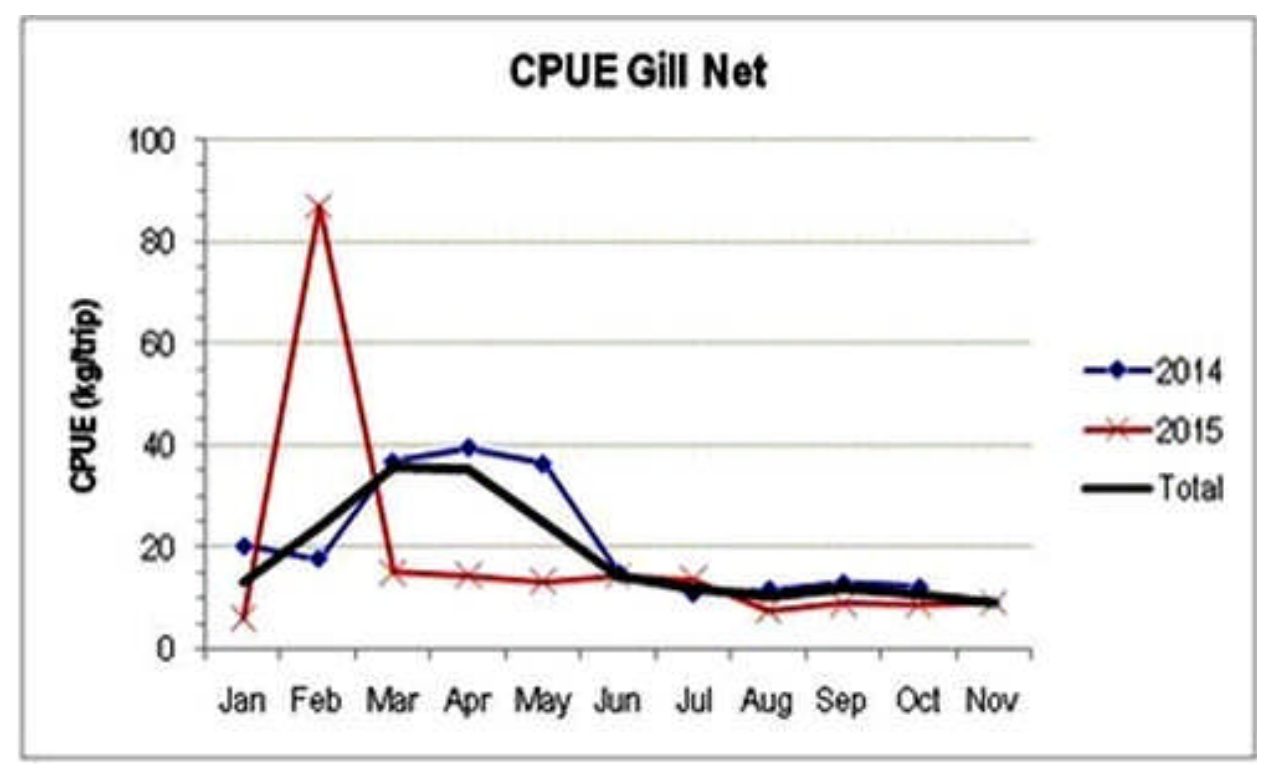

Gambar 6. Fluktuasi hasil tangkapan per unit upaya (CPUE) alat tangkap gill net di perairan estuarine Bengkalis (2014: Kecamatan Bengkalis, Bukit Batu dan Siak Kecil; 2015: Kecamatan Bukit Batu).

Figure 6. Fluctuation of catch per unit of effort (CPUE) of gill nets in around Bengkalis estuarine. 


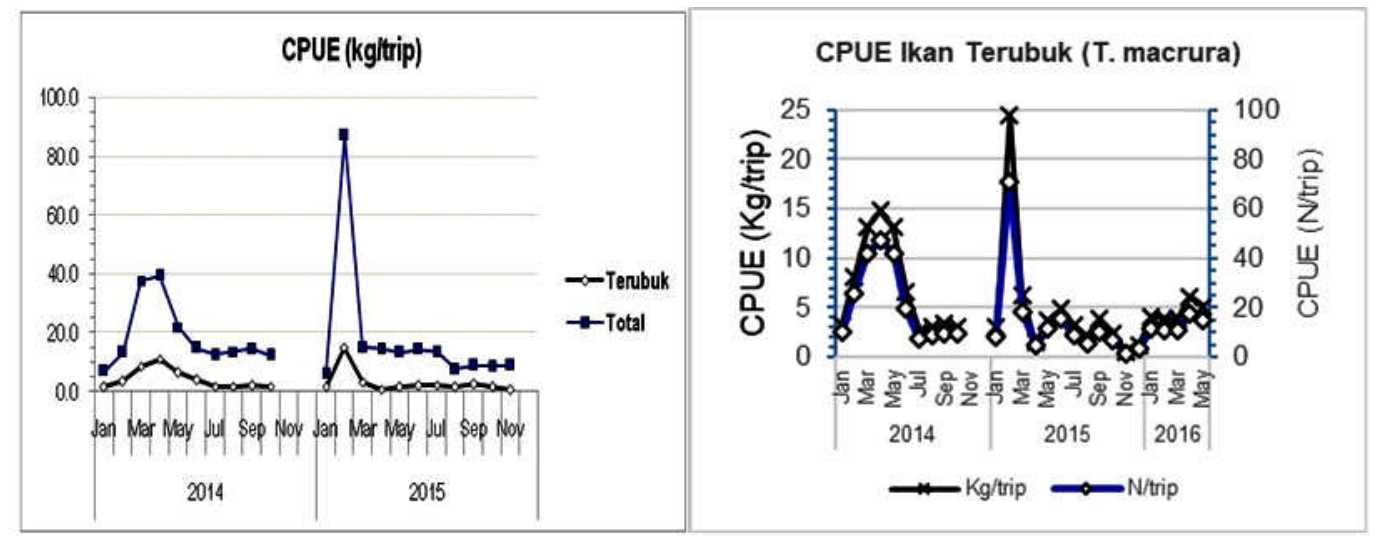

Gambar 7. Fluktuasi hasil tangkapan per unit upaya (CPUE, kg/trip) ikan pada alat tangkap gill net (kiri), dan CPUE ikan terubuk dalam $\mathrm{kg} /$ trip dan $\mathrm{N} /$ trip (kanan).

Figure 7. Fluctuation of catch per unit of effort (CPUE) of gill net (left) and CPUE of terubuk (right).

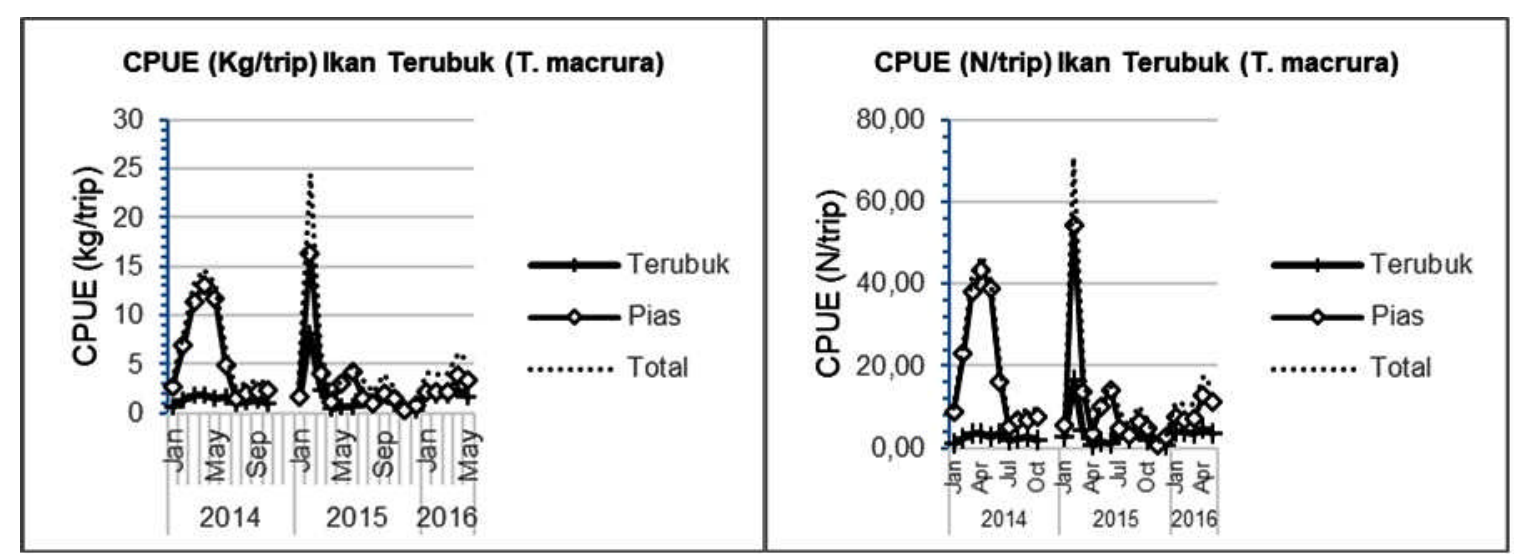

Gambar 8. Fluktuasi hasil tangkapan per unit upaya (CPUE) kategori 'terubuk' dan 'pias' dalam berat (kiri) dan jumlah (kanan).

Figure 8. Fluctuation of CPUE of "terubuk" and "pias" category in weight (left) and numbers (right).

Secara tahunan, selama periode 2014-2015 terlihat $\quad$ trip pada 2014-2015 (“pias"), dan peningkatan CPUE penurunan CPUE ikan terubuk dari 3,9 ekor/trip kembali pada 2016 sebesar 7,1 ekor/trip ("Terubuk") menjadi 1,8-2,7 ekor/trip ("terubuk") serta dari 22,6- dan 18,5 ekor/trip ("Pias") (Tabel 1).

26,9 ekor/trip pada 2012-2013 menjadi 2,0-5,9 ekor/

Tabel 1. Perubahan hasil tangkapan per unit upaya (CPUE) ikan terubuk (T. macrura) menurut kategori "Terubuk" dan "Pias" di perairan estuarine Bengkalis

Table 1. Changes of catch per unit of effort (CPUE) of terubuk (T. macrura) by category "Terubuk" and "Pias"in Bengkalis estuarine waters

\begin{tabular}{ccccc}
\hline CPUE & Tahun & "Terubuk" & "Pias" & Data \\
\hline & 2014 & 1,2 & 4,1 & Jan-Des \\
& 2015 & 0,8 & 0,7 & Jan-Des \\
N (Individu/trip) & 2016 & 3,8 & 2,4 & Jan-Mei \\
& 2012 & 3,9 & 26,9 & Jan-Des \\
& 2013 & 1,8 & 22,6 & Jan-Mar \\
& 2014 & 2,7 & 2,0 & Jan-Des \\
& 2015 & 2,0 & 5,9 & Jan-Des \\
& 2016 & 7,1 & 18,5 & Jan-Mei \\
\hline
\end{tabular}


Berdasarkan data CPUE ikan terubuk yang didaratkan di Bukit Batu serta dengan asumsi aktivitas penangkapan berlangsung dua kali dalam sebulan (periode bulan gelap dan bulan terang), lama waktu penangkapan masing-masing 5 dan 4 hari, jumlah nelayan jaring yang aktif di Bukit Batu sebanyak 44 orang, maka estimasi produksi pendaratan ikan terubuk di Kecamatan Bukit Batu sebesar 14,2 ton pada 2014 dan 9,5 ton pada 2015. Produksi rata-rata per bulan kira-kira 1,2 ton/bulan pada 2014 menjadi 0,8 ton/bulan pada 2015. Rincian estimasi pendaratan terubuk di Bukit Batu diperlihatkan dalam Tabel 2.
Sex ratio (nisbah kelamin) antara kategori 'Terubuk' (ikan betina dewasa matang) dan 'Pias' (ikan jantan dewasa) ikan dewasa bervariasi baik antara lokasi maupun waktu (Gambar 9). Berdasarkan pendaratan ikan terubuk di Kecamatan Bukit Batu periode 20142016 (Mei), dalam jumlah berat $(\mathrm{kg})$ sex ratio antara kategori Terubuk : Pias adalah $25: 75$ (\%), tetapi dalam jumlah individu (n) sex ratio berubah menjadi $16: 84(\%)$. Dalam skala tahun, terlihat peningkatan prosentase jumlah individu kategori 'Terubuk' dan penurunan prosentase jumlah individu kategori 'Pias'.

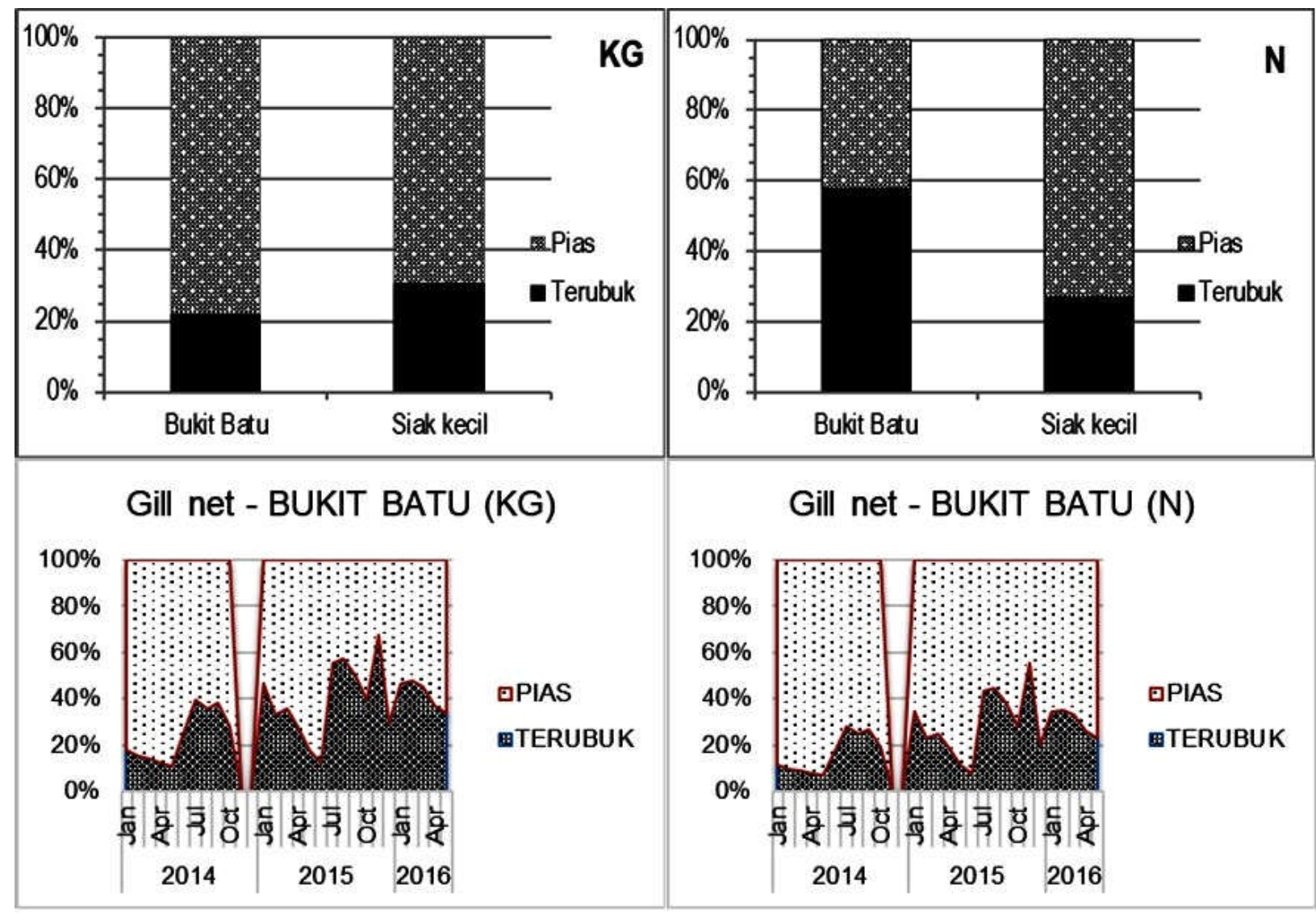

Gambar 9. Perbandingan antara kategori 'terubuk' (betina) dan 'pias' (jantan) dan variasinya menurut bulan, 2014-2016.

Figure 9. Monthly comparison of category of "terubuk" (female) and "pias" (male) category, 2014-2016. 
Tabel 2. Upaya penangkapan (trip), CPUE, dan nilai dugaan produksi pendaratan ikan terubuk di Kecamatan Bukit Batu pada 2014-2015.

Table 2. Effort (number of trips), CPUE and catch estimation of terubuk in the district of Bukit Batu in 2014-2015.

\begin{tabular}{|c|c|c|c|c|c|c|c|c|c|c|}
\hline \multirow[b]{2}{*}{ Th. } & \multirow[b]{2}{*}{ BI. } & \multirow{2}{*}{$\begin{array}{c}\text { Trip } \\
\mathrm{N}\end{array}$} & \multicolumn{2}{|l|}{ CPUE } & \multicolumn{2}{|c|}{ Trip } & \multicolumn{2}{|c|}{ Trip } & \multicolumn{2}{|c|}{ Total } \\
\hline & & & $\mathrm{Kg} /$ trip & $\begin{array}{c}\text { No. of } \\
\text { Fishermen }\end{array}$ & $\begin{array}{l}\text { Full- } \\
\text { moon }\end{array}$ & $\begin{array}{l}\text { Dark- } \\
\text { moon }\end{array}$ & $\begin{array}{l}\text { Full- } \\
\text { moon }\end{array}$ & $\begin{array}{l}\text { Dark- } \\
\text { moon }\end{array}$ & KG & TON \\
\hline \multirow[t]{12}{*}{2014} & Jan & 26 & 1,0 & 44 & 176 & 220 & 182,1 & 182,1 & 364,2 & 0,3 \\
\hline & Feb & 28 & 2,4 & 44 & 176 & 220 & 430,6 & 430,6 & 861,1 & 0,8 \\
\hline & Mar & 240 & 6,5 & 44 & 176 & 220 & $1.149,0$ & $1.149,0$ & $2.298,0$ & 2,3 \\
\hline & Apr & 186 & 8,4 & 44 & 176 & 220 & $1.478,9$ & $1.478,9$ & 2957,7 & 2,9 \\
\hline & May & 36 & 4,7 & 44 & 176 & 220 & 824,8 & 824,8 & $1.649,5$ & 1,6 \\
\hline & Jun & 16 & 3,9 & 44 & 176 & 220 & 685,3 & 685,3 & $1.370,6$ & 1,3 \\
\hline & Jul & 104 & 1,5 & 44 & 176 & 220 & 255,4 & 255,4 & 510,7 & 0,5 \\
\hline & Aug & 105 & 1,6 & 44 & 176 & 220 & 281,1 & 281,1 & 562,2 & 0,5 \\
\hline & Sep & 89 & 1,8 & 44 & 176 & 220 & 313,0 & 313,0 & 626,1 & 0,6 \\
\hline & Oct & 107 & 1,8 & 44 & 176 & 220 & 318,1 & 318,1 & 636,2 & 0,6 \\
\hline & $\begin{array}{l}\text { Oct } \\
2014\end{array}$ & & & & & & $.5 .918,2$ & $5.918,2$ & $11.836,4$ & 11,8 \\
\hline & (est.) & & & & & & $7.101,8$ & $7.101,8$ & $1.4203,7$ & 14,2 \\
\hline \multirow[t]{13}{*}{2015} & Jan & 44 & 1,3 & 42 & 168 & 210 & 218,2 & 218,2 & 436,4 & 0,4 \\
\hline & Feb & 10 & 14,5 & 42 & 168 & 210 & $2.427,6$ & $2.427,6$ & $4.855,2$ & 4,8 \\
\hline & Mar & 39 & 0,8 & 42 & 168 & 210 & 141,3 & 141,3 & 282,6 & 0,2 \\
\hline & Apr & 32 & 0,7 & 42 & 168 & 210 & 124,4 & 124,4 & 248,9 & 0,2 \\
\hline & May & 41 & 1,6 & 42 & 168 & 210 & 263,1 & 263,1 & 526,1 & 0,5 \\
\hline & Jun & 62 & 1,9 & 42 & 168 & 210 & 318,5 & 318,5 & 637,0 & 0,6 \\
\hline & Jul & 61 & 2,1 & 42 & 168 & 210 & 347,2 & 347,2 & 694,3 & 0,6 \\
\hline & Aug & 182 & 1,2 & 42 & 168 & 210 & 194,2 & 194,2 & 388,4 & 0,3 \\
\hline & Sep & 108 & 2,0 & 42 & 168 & 210 & 340,4 & 340,4 & 680,7 & 0,6 \\
\hline & Oct & 173 & 1,1 & 42 & 168 & 210 & 191,2 & 191,2 & 382,4 & 0,3 \\
\hline & Nov & 199 & 0,6 & 42 & 168 & 210 & 108,0 & 108,0 & 216,0 & 0,2 \\
\hline & $\begin{array}{l}\text { Dec } \\
2015\end{array}$ & 99 & 0,3 & 42 & 168 & 210 & 58,4 & 58,4 & 116,8 & 0,1 \\
\hline & (est.) & & & & & & $4.732,4$ & 4732,4 & $9.464,8$ & 9,4 \\
\hline
\end{tabular}

Keberadaan ikan Terubuk di Selat Panjang, Kabupaten Kepulauan Meranti

Selain di perairan sekitar Bengkalis berdasarkan hasil observasi lapangan ditemukan adanya aktivitas penangkapan ikan terubuk di sekitar Selat Panjang, Kabupaten Kepulauan Meranti. Penangkapan dilakukan dengan menggunakan gill net di daerah penangkapan sekitar P. Tiga di ujung selatan Selat Padang, kira-kira berjarak $140 \mathrm{~km}$ dari daerah penangkapan di Sungai Pakning (Gambar 10). Di daerah ini ikan terubuk masih menjadi target penangkapan terutama pada saat musim ikan terubuk, sedangkan jika tidak musim terubuk nelayan menangkap ikan tengiri, lomek dan puput. Tercatat sekitar 65 unit kapal jaring di sekitar Selat Panjang. Nelayan mengoperasikan jaring dengan menggunakan kapal motor dan perahu 'pompong' (sampan) bermotor. Panjang jaring terubuk dapat mencapai 60 piece $(20 \mathrm{~m}$ per piece), untuk menangkap ikan terubuk 'bertelur, mata jaring 23/4 inci dan 3 inci. 
Penangkapan ikan terubuk tersebar antara P. Tiga sampai sekitar Teluk Lanus (seberang Kepau) (Gambar 10). Namun, ikan terubuk juga dapat tertangkap di perairan antara Tanjung Samak dan P. Tiga dengan kelimpahan lebih sedikit. Nelayan penangkap terubuk terutama berasal dari Desa Kepau Baru (Kecamatan Tebing Tinggi Timur) dan beberapa desa di Tanjung Samak (Kecamatan Rangsang) dan Sekodi (Bengkalis). Di Selat Padang di sebelah utara Teluk Lanus hingga Mengkikip (Kecamatan Tebing Tinggi Barat) di sebelah selatan muara Sungai Pakning (daerah penangkapan terubuk oleh nelayan Bengkalis yang juga merupakan lokasi pemijahan terubuk) menurut nelayan tidak ada penangkapan. Di Tanjung Samak, Kecamatan Rangsang Pesisir, nelayan jaring menggunakan kapal ukuran 3-5 GT dibantu dengan mesin. Fishing ground umumnya di Selat Malaka, kira-kira 3 jam arah utara. Aktivitas penangkapan bersifat harian tapi bisa 3-4 hari. Jaring yang dipakai sebanyak 40-50 piece (20 m/piece), mata jaring 2 dan 2,5 inci. Hasil tangkapan jaring 2 inci berupa ikan ukuran lebih kecil termasuk 'Pias', sedangkan jaring 2,5 inci memperoleh ikan tenggiri dan parang. Seperti halnya di Prapat Tunggal (Meskom, Bengkalis) dan
Tenggayun (Bukit Batu), 'pias' juga sering dijumpai dalam jumlah sedikit pada hasil tangkapan gombang (alat tangkap pasang-surut bersifat pasif).

Menurut nelayan pada 1990an hingga 2000, ikan terubuk masih tertangkap cukup banyak, tetapi pada pasca tsunami (kira-kira selama 3 tahun) ikan terubuk hilang dan baru muncul kembali pada tahun-tahun terakhir (sekitar 2010) dan pada saat ini (2015) hasil tangkapan kategori 'Terubuk' (ikan betina dewasa atau bertelur) lebih banyak tertangkap dibandingkan hasil tangkapan 'Pias'. Pada saat musim ikan hasil tangkapan terubuk dapat mencapai 100-200 ekor per minggu, biasanya dibawa ke Tanjung Buton. Puncak musim penangkapan terubuk biasanya berlangsung antara Mei dan Agustus, bertepatan saat angin selatan-tenggara bertiup kencang di daerah ini; periode penangkapan berlangsung saat bulan terang (fullmoon) kira-kira selama 10-15 hari, puncak terjadi selama 3 hari yaitu tanggal 13-14-15 lunar calendar. Ikan terubuk yang tertangkap umumnya adalah ikan terubuk bertelor (female mature fish). Pada saat bulan gelap ikan terubuk lebih jarang tertangkap kecuali pada puncak musim (Mei sampai Agustus).

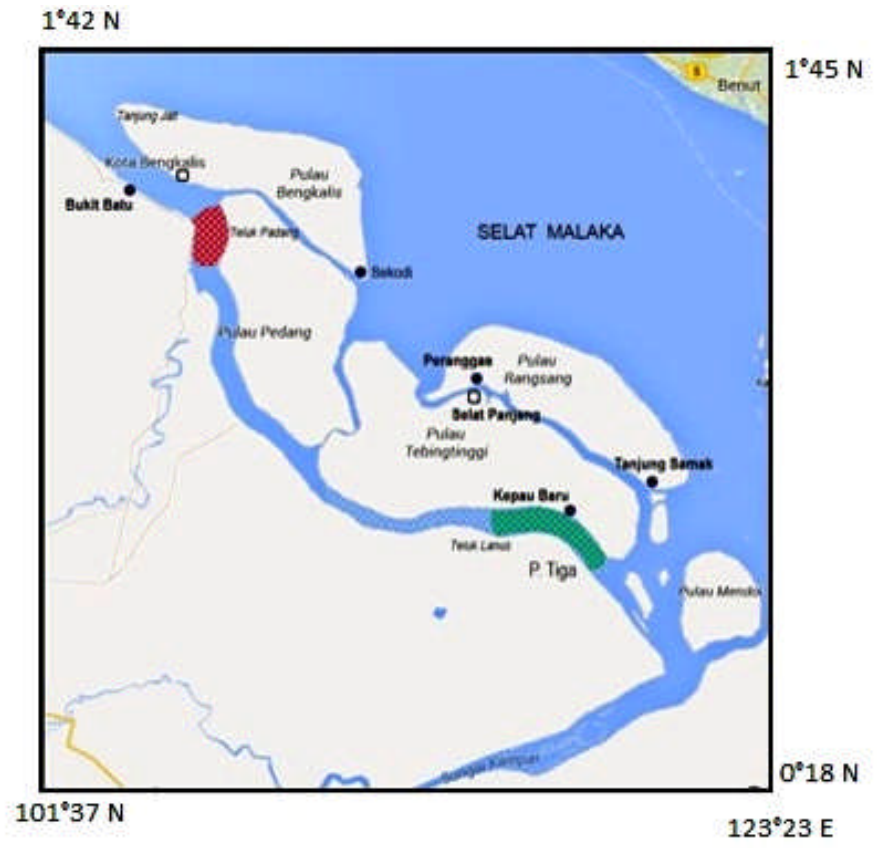

Gambar 10. Daerah penangkapan ikan Terubuk di sekitar Kab. Bengkalis (warna merah) dan di Selat Panjang, Kab. Kep. Meranti (warna hijau).

Figure 10. Main fishing grounds of terubuk in Bengkalis (red) and Selat Panjang, Kep. Meranti (green).

\section{Bahasan}

Perikanan Gill Net dan Penangkapan Ikan Terubuk

Gill net merupakan alat tangkap yang umum dipakai nelayan Bengkalis dan memberi kontribusi produksi paling besar. Ikan terubuk termasuk diantara empat jenis paling dominan (15\%) yang tertangkap jaring, tiga jenis lainnya adalah lomek, biang dan tenggiri yang lebih dominan di Selat Bengkalis. Dominasi ikan terubuk terutama terlihat di wilayah Kecamatan Bukit Batu (22\%) dan Siak Kecil (18\%), sedangkan di Kecamatan Bengkalis hanya 2\%. Dari kondisi ini menunjukkan suatu kenyataan bahwa nelayan masih menangkap ikan terubuk baik secara aktif maupun tidak, meskipun telah ditetapkan "status perlindungan terbatas" bagi jenis ikan terubuk ( $T$. 
macrura) dan "konservasi sumberdaya ikan" melalui Keputusan Menteri Kelautan dan Perikanan RI No. Kep. 59/Men/2011 tentang Penetapan Status Perlindungan Terbatas Jenis Ikan Terubuk, T. macrura; Peraturan Menteri Kelautan dan Perikanan RI No. Per. 03/Men/2010 tentang Tata Cara Penetapan Status Perlindungan Jenis Ikan, serta Peraturan Pemerintah RI No. 60 Tahun 2007 tentang Konservasi Sumberdaya Ikan. Penurunan hasil tangkapan terubuk pada saat close season dan close area (September sampai November, masing-masing selama 3 hari pada periode bulan gelap) pada 2014 memang terlihat, tetapi terjadi peningkatan kembali pada 2015 (Gambar 4). Hal tersebut juga ditegaskan oleh pola upaya penangkapan gill net dimana tidak terjadi penurunan yang signifikan dari jumlah upaya (trip) per nelayan seperti ditunjukkan pada Gambar 6 (dari 19 trip/ nelayan pada 2014 menjadi 18 trip/nelayan pada 2015). Penangkapan nelayan biasanya bersifat acak menuju kepada gerombolan ikan berada, sedangkan pada bulan-bulan antara September sampai November gerombolan ikan terubuk diketahui terkonsentrasi di perairan sekitar lokasi pemijahan (perairan Sungai Pakning, Selat Padang) (Blaber et al., 1999; Merta et al., 1999; Suwarso, 2000). Tingginya frekuensi penangkapan di sekitar S. Pakning dan P. Padang ditunjukkan pada Gambar 5.

\section{Perubahan Hasil Tangkapan Ikan Terubuk}

Hasil tangkapan per unit upaya (kg/trip) gill net secara umum lebih besar dibandingkan dengan alat lain. Selain itu hasil tangkapan gill net Bengkalis juga lebih tinggi dibandingkan dengan hasil dari gill net Bukit Batu dan Siak Kecil dan kontribusi ikan tengiri diduga menentukan hasil tangkapan ini. Pola musiman hasil tangkapan dengan dua puncak musim cenderung terlihat dimana hasil yang lebih besar ditunjukkan antara Februari sampai Mei. Pola musiman demikian juga dapat terlihat pada hasil tangkapan ikan terubuk. Jika CPUE alat jaring sekitar 23,3 kg/trip, maka CPUE ikan terubuk diperkirakan sekitar 4,5 kg/trip. Berdasarkan nilai CPUE sebagai indek kelimpahan ikan maka puncak tangkapan alat gill net secara umum terjadi antara Maret sampai Mei (2014). Sebagai kelompok jenis hasil tangkapan (CPUE dalam kg/trip) ikan terubuk (gabungan antara kategori 'terubuk' dan 'pias') lebih tinggi sekitar Maret-April (8-10 kg/trip).

Secara umum kategori 'Pias' tetap lebih dominan dibandingkan dengan 'Terubuk', pola fluktuasi keduanya hampir bersamaan; selain itu, pola musiman hasil tangkapan terubuk sangat jelas ditentukan oleh kelompok 'Pias'. Dominasi kategori 'Pias' ditegaskan dengan jelas pada data sex ratio antara kategori
'Terubuk' dan 'Pias' seperti diperlihatkan pada Gambar 8. Dalam satuan berat sex ratio "Terubuk : Pias" sebesar 1 : 3 (25\% : 75\%) berubah menjadi 1 : 5,25 (16\% : 84\%) dalam satuan jumlah ekor (data Bukit Batu). Terkait berat rata-rata ikan maka sex ratio dalam satuan individu ini dimungkinkan lebih nyata dari sex ratio populasi ikan terubuk dewasa. Dengan demikian, jumlah individu ikan "Terubuk" diduga hanya sebanyak $16 \%$ dibanding "Pias" yang lebih banyak (84\%). Data bulanan sex ratio juga menegaskan adanya perubahan/peningkatan prosentase kategori "Terubuk" pada saat musim pemijahan antara September-November. Sex ratio ini sangat berbeda dengan kondisi pada 1996-1998 (kira-kira selang 18 tahun) dimana pada kurun tersebut ratio antara "Terubuk" : "Pias" adalah 45\% : 55\% (Merta et al., 1999; Suwarso et al., 1999; Suwarso, 2000) yang menunjukkan jumlah populasi kategori "Terubuk" pada kurun waktu itu lebih banyak (sekitar 45\%) dibandingkan dengan saat ini (hanya 16\%). Penurunan produksi ikan terubuk juga terjadi secara signifikan dalam selang waktu 18 tahun. Suwarso \& Merta (1997) mengestimasi produksi terubuk pada kurun 1996-1998 berkisar antara 0,5-10 ton/bulan atau 4-37 ribu ekor/bulan, sedangkan saat ini turun menjadi 0,12-4,9 ton/bulan (rata-rata 0,97 ton/bulan).

Dalam konteks penurunan populasi terubuk secara umum penurunan nilai CPUE masing-masing kategori antara tahun 2014-2015 seperti terlihat dalam Tabel 1 yang menunjukkan indikasi kepatuhan nelayan pada peraturan pemerintah tentang pembatasan penangkapan serta kesadaran lingkungan, tetapi peningkatan CPUE kembali pada 2016 memperlihatkan turunnya komitmen dalam hal membatasi penangkapan ikan terubuk. Kepatuhan nelayan ini terutama terkait dengan penangkapan di sekitar lokasi pemijahan terubuk (sekitar PakningTeluk Padang) yang telah ditutup untuk penangkapan (close area) selama September sampai November (close season) pada periode musim pemijahan terubuk (3 hari pada periode bulan gelap). Mengingat pentingnya perlindungan terhadap'spawning stock' terubuk di wilayah ini, maka hal ini perlu mendapat perhatian serius.

\section{Eksistensi Ikan Terubuk di P. Tiga (Kabupaten Kepulauan Meranti)}

Keberadaan ikan terubuk di daerah Selat Panjang sebenarnya telah diketahui sejak lama (antara 19961998), sebagian kecil terdata pada kerjasama penelitian antara Indonesia-BPPL dengan AustraliaCSIRO), namun hasil tangkapan di P. Tiga kurang tercatat. 
Berdasarkan ciri meristik dan morfologi jenis ikan terubuk yang tertangkap di sekitar di P. Tiga - Teluk Lanus (Kabupaten Kepulauan Meranti) diduga sama dengan yang ada di sekitar Bengkalis, yaitu Tenualosa macrura. Uji genetik melalui analisis kesamaan DNA mitochondria dengan prinsip RFLP (Restriction Fragment Length Polymorphism) menunjukkan pola-pola sebaran dan ukuran band-band DNA yang sama antara populasi contoh dari Bengkalis dengan populasi P.Tiga (Zamroni \& Suwarso, 2016; unpublish), sehingga meyakinkan kedua populasi adalah spesies yang sama, yaitu T. macrura. Analisis dilaksanakan dengan 'primer' 16SAR dan 16SBR dan 9 jenis enzym restriksi (Alu I, Hae III, Hap II, Hin 6I, Hind III, Hinfl, Mbo I, Rsa I dan Xba I) terhadap masingmasing delapan contoh jaringan (daging) tiap lokasi.

Selanjutnya, hasil pengamatan biologi terhadap 13 ekor ikan sampel yang termasuk kategori terubuk 'telur' (fully mature female) yang diperoleh dari hasil tangkapan pada periode bulan terang (full-moon) September 2014, memperlihatkan ukuran berkisar antara 25,0-31,2 cm SL atau 26,1-32,7 cm FL, berat antara 327-652 gram. Berat gonad segar (ovary) antara 3060 gram, indek kematangan gonad (Gonado Somatic Index, GSI) antara 8-13\% (rata-rata=10,5\%). Secara visual kondisi kematangan gonad dalam tahap TKG III atau 'late-maturing'. Kondisi kematangan terlihat sedang menuju ke tingkat 'fully mature' (TKG IV). Secara visual ukuran gonad telah memenuhi rongga perut, warna merah-orange dengan butir telur yang besar tapi belum menunjukkan penampakan telur gravid/translucent yang bening. Hal tersebut masih perlu beberapa waktu (antara 1 sampai 2 bulan) untuk menjadi benar-benar 'matang' (fully-mature fish) dan siap memijah. Hasil penelitian Blaber et al. (1999); Brewer \& Blaber (1997); Merta et al. (1999); Suwarso (2000) tampak puncak pemijahan ikan terubuk di perairan Bengkalis diyakini berlangsung antara September sampai Nopember, selama 3-5 hari pada puncak periode gelap dan terang tiap bulan. Masih diperlukan penjelasan lebih detil tentang saling keterkaitannya, spawning stock terubuk di P. Tiga diperkirakan memiliki peranan dalam life history terubuk secara luas. Terkait hal tersebut perluasan daerah terhadap status "perlindungan terbatas" (Kep. 59/Men/2011 dan Per. 03/Men/2010) dan konservasi jenis (PP. No. 60/2007) secara umum terhadap ikan terubuk penting dipertimbangkan, bukan hanya di sekitar Bengkalis tetapi dapat mencakup ke wilayah Kabupaten Kepulauan Meranti ini.

\section{KESIMPULAN}

Perikanan gill net dominan di sekitar Bengkalis, masih tingginya hasil tangkapan ikan terubuk (sekitar
$15 \%$ diantara enam jenis dominan lainnya) dan upaya penangkapan yang cukup intensif menjadi indikasi kurangnya komitmen perlindungan jenis serta kecenderungan adanya aktivitas 'berburu' oleh nelayan; penurunan upaya yang mesti dilakukan ternyata kurang signifikan bahkan pada saat close season dan close area. Kondisi ini sebaiknya dikembalikan kepada tujuan "perlindungan terbatas" dan konservasi jenis" ikan terubuk secara utuh melalui pembatasan penangkapan secara lebih ketat. Dalam pola fluktuasi hasil tangkapan yang bersamaan selain terjadi perubahan hasil tangkapan (CPUE) dalam kurun 2012-2016 karena terkait dengan faktor 'komitmen' dan kepatuhan. Secara global dalam selang waktu kira-kira 18 tahun telah terjadi penurunan populasi (CPUE) dan produksi secara nyata; kategori "Terubuk" makin sedikit, sedang "Pias" semakin banyak, artinya ukuran rata-rata ikan tertangkap juga semakin kecil.

Keberadaan ikan terubuk di perairan P. Tiga (Kabupaten Kepulauan Meranti) paling tidak mengindikasikan adanya spawning stock lain yang secara genetik diduga merupakan genetic stock yang sama dengan spawning stock ikan terubuk di sekitar Bengkalis. Perluasan daeran konservasi dan perlindungan terbatas terhadap stok - stok tersebut sangat disarankan.

\section{PERSANTUNAN}

Penelitian ini merupakan kontribusi dari kegiatan penelitian Balai Penelitian Perikanan Laut tahun 20142015 yang berjudul "Kajian Stok, Distribusi dan Parameter Biologi Sumberdaya Ikan Pelagis Kecil untuk Mendukung Industrialisasi Perikanan di WPP 571 dan 711" yang didanai oleh APBN 2014-2015.

\section{DAFTAR PUSTAKA}

Ahmad, M., T. Dahril \& Efison, D. (1995). Ekologi Reproduksi Ikan Terubuk (Alosa toli) di perairan Bengkalis, Riau. Jurnal Perikanan dan Kelautan, 1, 2-19.

Anonim. (2007). Peraturan Pemerintah Republik Indonesia Nomor 60 Tahun 2007 Tentang Konservasi Sumber Daya Ikan. Departemen Kelautan dan Perikanan, DirJen Kelautan, Pesisir dan Pulaupulau Kecil, Dir. Konservasi dan Taman Nasional Laut.

Anonim. (2011). Peraturan Menteri Kelautan dan Perikanan Republik Indonesia Nomor Per.03/Men/ 2010 Tentang Tata Cara Penetapan Status Perlindungan Jenis Ikan. Kementerian Kelautan 
dan Perikanan, DirJen. Kelautan. Pesisir, dan Pulau-pulau Kecil, Dir. Konservasi dan Taman Nasional Laut.

Anonim. (2011). Keputusan Menteri Kelautan dan Perikanan Republik Indonesia Nomor Kep.59/Men/ 2011 Tentang Penetapan Status Perlindungan Terbatas Jenis Ikan Terubuk (Tenualosa macrura). Kementerian Kelautan dan Perikanan, DirJen. Kelautan. Pesisir, dan Pulau-pulau Kecil, Dir. Konservasi dan Taman Nasional Laut.

Blaber, S. J. M., Brewer, D. T., Milton, D. A., Merta, G. S.,Efison, D., Fry, G., \& van der Velde, T. (1999). The life history of the Protandrous Tropical Shad Tenualosa macrura (Alosinae : Clupeidae) : Fishery Implications. Estuarine, Coastal and Shelft Science, 49, 689 - 701.

Brewer, D. \& Blaber, S. J. M. (1997). Reproductive ecology and life history of Tenualosa macrura in Bengkalis. $1^{\text {st }}$ Co-ordination Meeting on Terubuk Fishery. Pekanbaru, 23-24 July 1997.

Gloerfelt, T. \& Kailola, T. P. J. (1980). Trawled Fishes of Southern Indonesia Nad Northwestern Australia. The Australian Development Assistance Bureau - The Directorate General of Fisheries, Indonesia - The German Agency for Technical Cooperation.

Merta, I. G. S., Suwarso, Wasilun, Wagiyo, K., Girsang, E. S., \& Suprapto. (1999). Status populasi dan bio-ekologi ikan terubuk, Tenualosa macrura (Clupeidae) di propinsi Riau. J.Lit.Perikan.Ind. 5(3), 15 - 29.
Munroe, T.A., Wongratana, T., \& Nizinski. (1999). CLUPEIDAE. Dalam: FAO Species Identification Guide for Fishery Purposes. The Living Marine Resources of the Western Central Pasific. FAO. Rome.

Suwarso \& Merta, I.G. S. (1997). Kelimpahan Populasi Ikan Terubuk, Tenualosa macrura (Clupeidae) dan Dugaan Produksinya di Perairan Estuarin sekitar Bengkalis (Riau). Simposium Perikanan Indonesia II, Ujung Pandang, 23-24 September 1997. 99 $-103$.

Suwarso. (2000). Penurunan populasi dan alternatif pengelolaan ikan Terubuk, Tenualosa macrura (Clupeidae), di Propinsi Riau. Prosiding Seminar Nasional Keanekaragaman Hayati Ikan. ISBN: 979-9583-4-8.

Suwarso. (2014). Sumber daya Ikan Terubuk (Tenualosa sp.) di perairan pantai Pemangkat, Kalimanan Barat. Seminar Nasional Ikan VIII dan Konggres IV Masyarakat Iktiologi Indonesia. Bogor, 3-4 Juni 2014. 12 hal.

Suwarso \& Merta, I. G. S. (1997). Kelimpahan populasi ikan Terubuk, Tenualosa macrura (Clupeidae) dan dugaan produksinya di perairan estuarin sekitar Bengkalis (Riau). Simposium Perikanan Indonesia II, Ujung Pandang, 23-24 September 1997. 99103.

Zamroni, A. \& Suwarso. (2016). Status biologi ikan terubuk (Tenualosa macrura) di Kab. Kepulauan Meranti. Unpublished. 